R. Thomas Jones

Architect; A.I.A.

Dean, College of Architecture and Environmental Design,

Cal Poly San Luis Obispo

\section{Expanding Housing Choices, Conserving Coastal Counties}

In this article ${ }^{1}$, Dean Jones discusses housing choices in California, one of the themes around which he built his professional career. He is a long time advocate of and has been directly involved with socially and environmentally responsive design, affordable housing, community planning, and smart growth. He co-authored the book "Good Neighbors: Affordable Family Housing" (McGraw Hill, 1995).

As Coastal counties continue to grow, can we really imagine our towns and countryside also growing better? It may be that by expanding housing choices to include more compact and land conserving types, we can also improve our towns and countryside. That appears to be one of the conclusions made when 140 citizens and planning officials gathered on March 11 In San Luis Obispo to review and vote on the ideas generated from two earlier countywide visioning sessions.

Compact housing, which is a key concept of the smart growth movement, has certainly caught on in the major metro areas, but the idea was once considered unrealistic in rural markets. However, new trends have emerged over the last five years suggesting both buyer demand and builder interest in compact housing in coastal areas. With new live-work lofts attracting former Montecito residents into downtown Santa Barbara, housing over shops slated for Atascadero, and ecologically planned communities preserving vulnerable landscapes in Carmel, there are some exciting new development models in our regions that are reducing the usual impact on the environment and creating new ways of living.

A combination of factors are leading to the "back to the town" compact housing movement, including the high cost of building and maintaining large homes on large lots, the social isolation of remote homes, a need to shorten commuting, and a desire to be closer to town conveniences like shops, cultural activities, and walkable neighborhoods. Younger couples and those whose children have grown are two groups who are gravitating toward compact homes near town. In particular, the housing choices sought by those over 55, who are slated to become a greater proportion of our coastal population, will greatly shape the region. Indications are that many will seek an alternative to the single family detached home on a larger lot at some point, and that health or sociability, not just cost, will be a major factor in the decision.

\footnotetext{
1 This article was originally published in the Central Coast Magazine, April 2005.
}

For those who still seek a rural setting within an agricultural or forested area, there is also an emerging market for homes that require fewer materials and energy resources to construct and maintain, as the idea of living more sustainably has also garnered interest recently with segments of the builder and buyer communities. The compact housing movement is growing due to a " 3 -D" combination of demographics, demand, and design.

Based on my own studies, including conversations with a variety of builders, environmentalists, and governmental representatives, the following is the list of the different housing types for which the coast will potentially see more consumer demand. What they all have in common is they take less land away from farming or nature, require fewer roads to support, are better at conserving water and other resources, and meet the needs of a broader cross section of our population than the average new single family home. Additionally, experts have shown that compact homes close to town help bolster local small businesses while reducing traffic congestion. Compact housing turns out to provide several public benefits then, in addition to meeting growing private needs.

\section{Town Housing Types}

- Small Lot Homes (Fig. 1) - Many buyers and communities have found that by shrinking side yards and front yards and narrowing the streets, and using more small-scale architectural design features, homes on small lots can look and feel compatible with standard lot homes, yet save $20-40 \%$ more land. If some of the land saved by creating small lot homes can be used to create a neighborhood park, the experience may actually make small lot communities feel more spacious, and they provide more forms of outdoor activities, than conventional subdivisions.

- Secondary Units (Fig. 2) - State law now mandates all communities allow for these. It is important to design 
also work well when used to line a pedestrian-only mews or semi-private lane between two streets, with parking for the residents at the ends. Mews townhomes originated in New York and San Francisco, where they begun as affordable homes for the tradesmen, but have evolved to be a very fashionable house type nowadays.

- Live-Work Lofts (Fig. 6) - the idea of having a tall ceiling open plan space with a sleeping loft above for both living in and doing work originated as artists converted old warehouse lofts into illegal residences in New York. Originally conceived of as an urban, big city building type, they have now succeeded in smaller cities and are being built as a new building type. They also appeal to a broader number of individuals than just artists and singles as working at home has grown tremendously. No longer limited to the Bay Area and the LA/San Diego regions, they are attracting buyers from Sacramento to Santa Barbara, and soon will come to San Luis Obispo and Nipomo.

- Mixed Use Condominiums (Fig. 7) - Living above stores and restaurants has always been considered one of the most urban housing types. Mixing housing with other uses is also one of the most challenging building types to design or finance. Older towns all have some building where people lived above the stores, but land use controls and lending practices saw such buildings fall out of favor for many years. Now even cities as small as Atascadero are being considered as good places to locate mixed use, multiple story buildings. The proposed three story, 72 unit Colony Square in that city will feature new shops and restaurants plus a new movie theater, and also

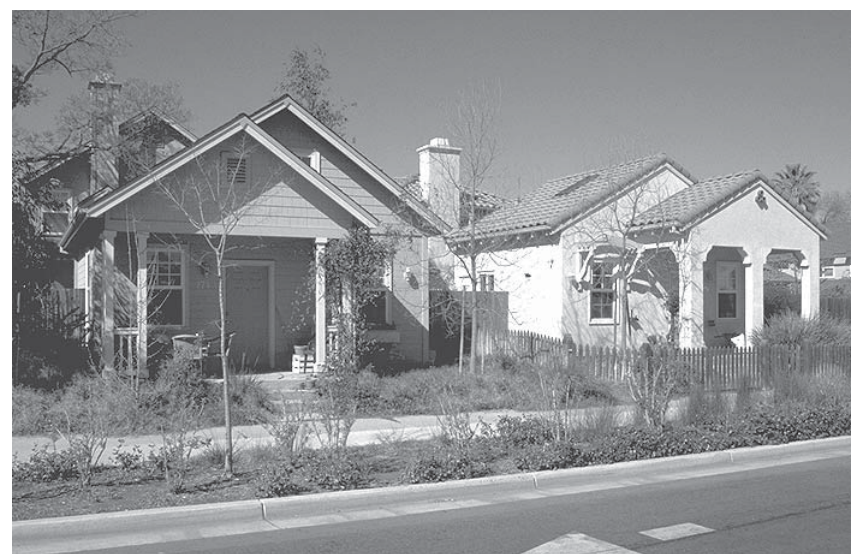

Figure 1. Small lot homes. Metro Square, Sacramento. (photo by author) and site them well to fit in with traditional homes. Some designers have reintroduced the idea of a small rental unit over a garage facing a back alley or a cottage at the back of the lot as a good approach. This house type is attracting major interest among buyers who foresee themselves as caregivers for aging parents or value the rental income provided by a second unit.

- Bungalow and Cottage Courts (Fig. 3) - California invented the idea of clustering six to ten cottages or small homes around a shared courtyard, with common parking behind. This 1920's era creation started in Hollywood, and is being revived as a good model for small town senior housing, or for entry-level housing where a shared kids play area is the focus of the courtyard.

- Manses (Fig. 4) - not to be confused with mansions, the "manse" is a two to six unit building designed to look like one very large home. This idea comes from the rural east coast, where developers who were required to build affordable housing as a condition for getting approval for large market rate homes wanted to provide housing that was compatible with large new homes nearby. Several California versions have taken the form of looking like large old farmhouses, old Victorian mansions, or large Arts and Crafts era homes.

- Townhomes and Mews Homes (Fig. 5) - Sometimes called townhouses, row houses, or attached houses, there are some 1960's to 80's townhome style developments in central coast areas, but they went out of favor. To work best, they should not be isolated in clusters at the edges of town and surrounded by parking, but fronted on attractive walking streets and be near conveniences. Townhouses

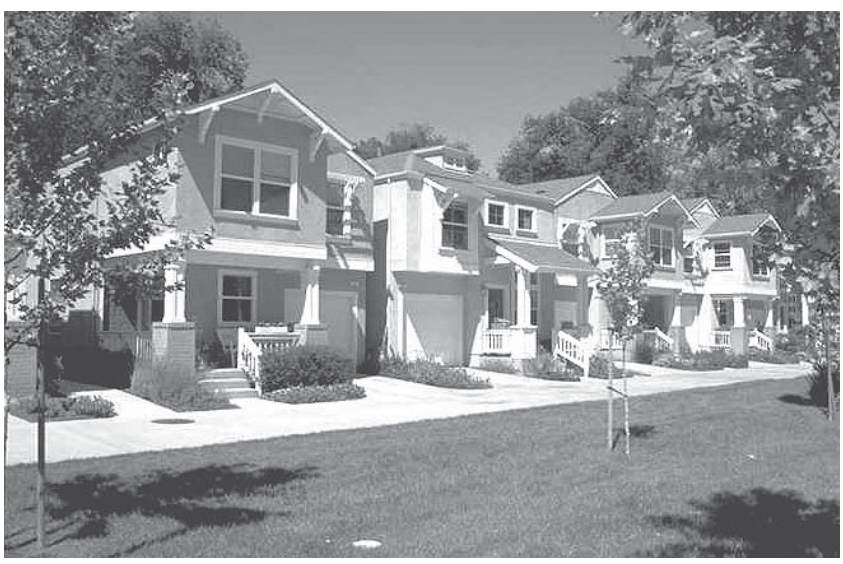

Figure 2. Secondary units. Aggie Village, Davis. (photo by author) 


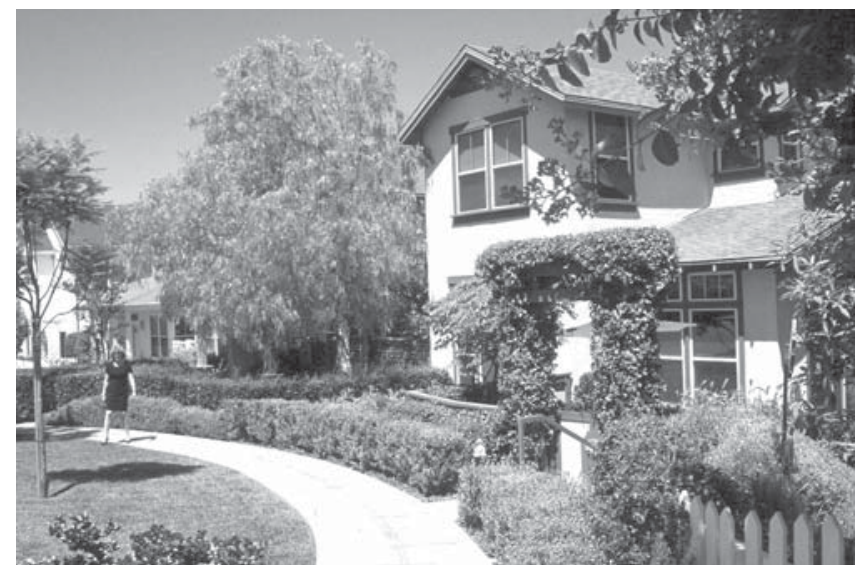

Figure 3. Bungalows and Cottage Courts. Ash Street Cottages, Brea. (photo courtesy The Local Government Commission)

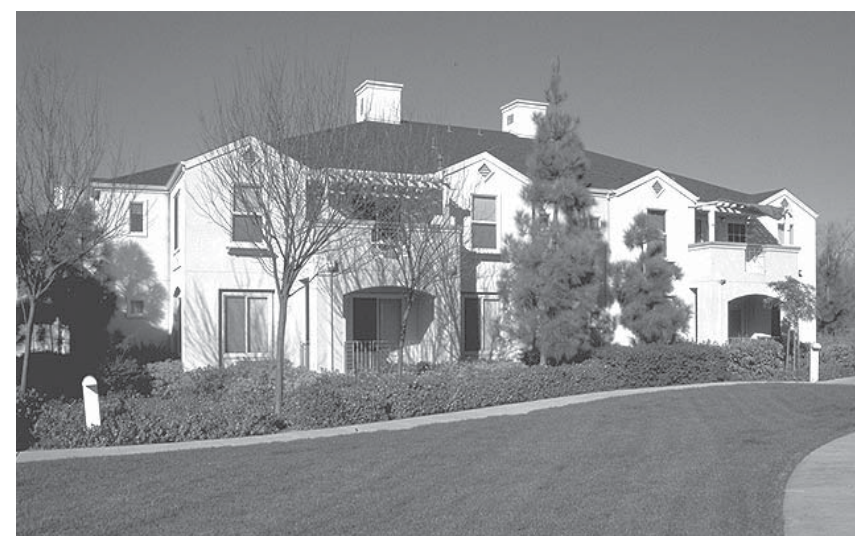

Figure 4. Manses. Crescendo Oaks, San Jose. (photo by author)

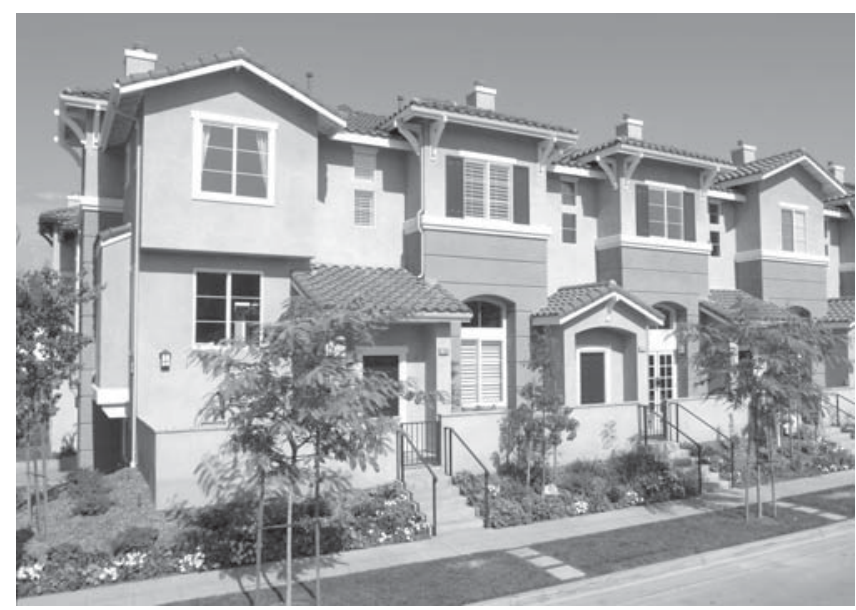

Figure 5. Townhomes. Plaza Walk, Fullerton. (photo courtesy The Olsen Company) include a 15,000 square foot city hall plus public square. Mixed use buildings rising to four or even five stories would not be out of scale with some of the taller old buildings in the downtown blocks of our larger Central Coast cities.

\section{In Country Housing Types}

- Co-housing in Extended Farmhouses and Rural Villas (Fig. 8) - The co-housing movement originated in Denmark, wherein a group of people jointly hires an architect, finds a site, and creates a cluster of homes that share common spaces. The co-housing model can take many forms, but a new possible one will be the creation of rural shared homes for small group retirees who want to live in the country while having proximity to old friends. Current zoning for agriculture areas may not permit the development of shared farmhouses or villas, and would instead require subdivision into separate home sites which requires more paving, fences, infrastructure runs, and changing the character of the surrounding area. I predict more interest in developing shared housing models that fit unnoticed into rural agricultural and natural areas as a new housing type that could be more desirable for the landscape as well as for the owners.

- Sustainable Living (Fig. 9) - Sometimes referred to as Green Architecture or living light on the land, the desire to be more environmentally friendly motivates an increasing number of buyers, regardless of the housing type they select. This means building in a way that leaves very little of the natural landscaped disturbed by the building process, harnessing solar power to heat water and generate electricity, and even collecting rainwater

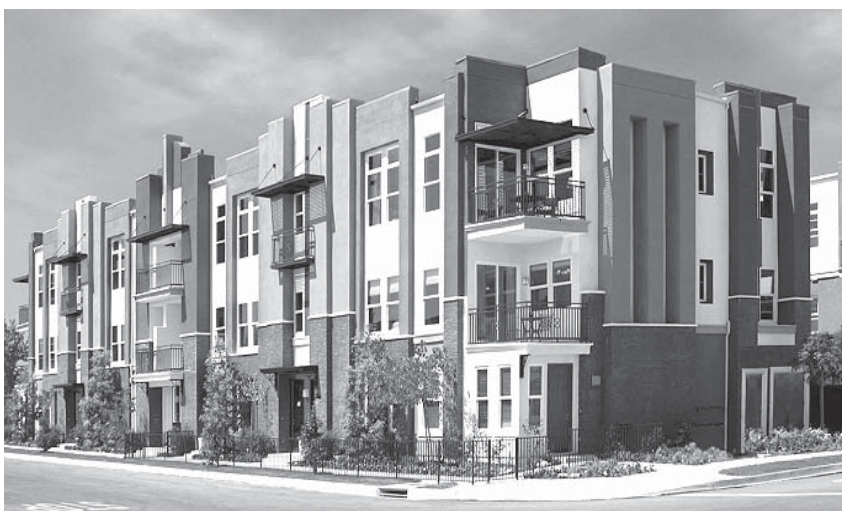

Figure 6. Live-work. Claremont Village Walk, Claremont. (photo courtesy The Olsen Company) 
and recycling gray water so as to limit the impact on groundwater resources. These techniques can also be used to fit clusters of homes, or small scale resorts, into the coastal environment. Though some components of sustainable systems require more initial investment, they offer lower operating costs over time.

The emerging trends in compact housing are coinciding nicely with what the citizens and planners say we need for a better future. Providing compact housing does not mean limiting access to traditional housing. The goal of planning more areas for compact and sustainable homes is to expand housing choice while also better conserving our Central Coast towns and countryside.

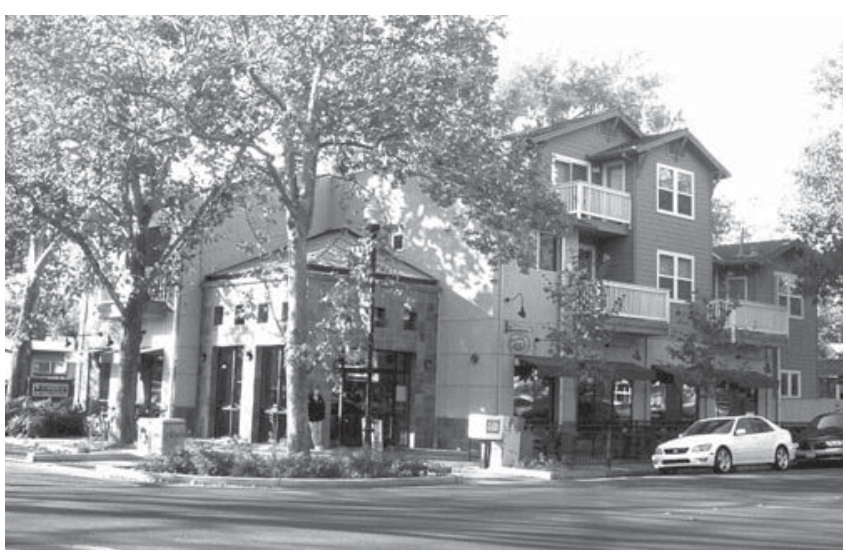

Figure 7. Mixed use condos. Downtown, Davis. (photo courtesy The Local Government Commission)

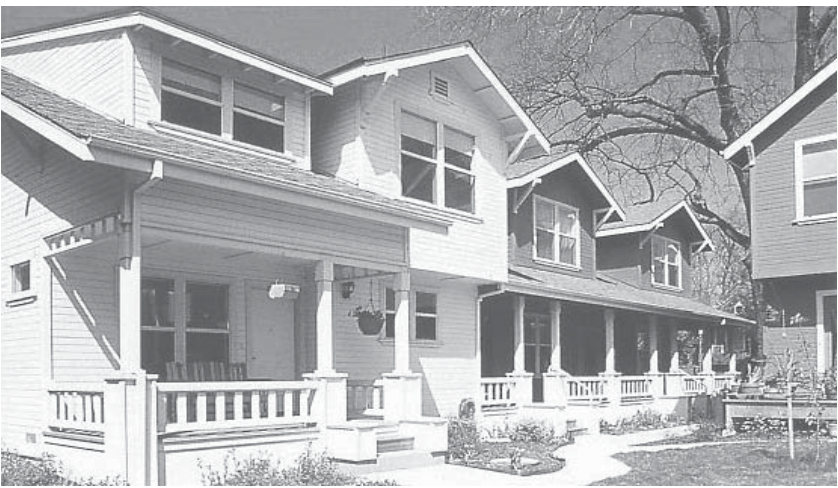

Figure 8. Co-op housing. Southside Park, Sacramento. (photo by James Kline)

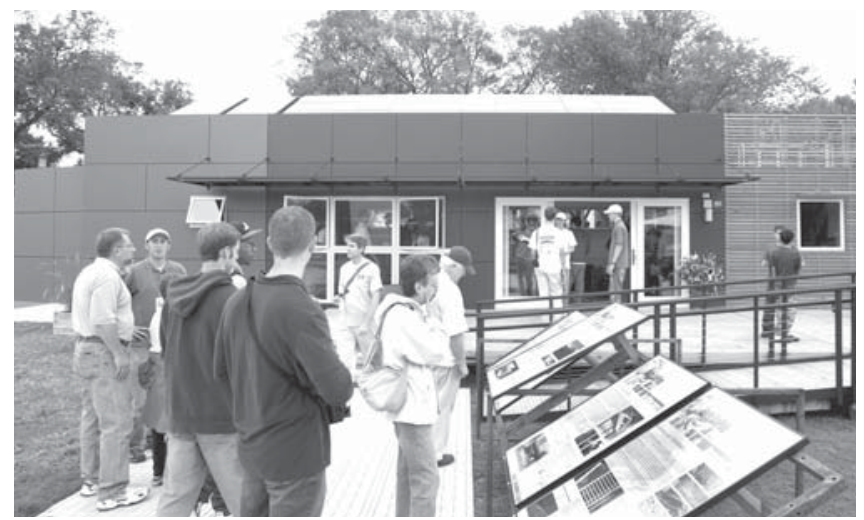

Figure 9. Sustainable Living. The CAED Cal Poly prototype of green house for the 2005 Solar Decathlon. 